\title{
The role of national trade logistics in the export trade of African countries
}

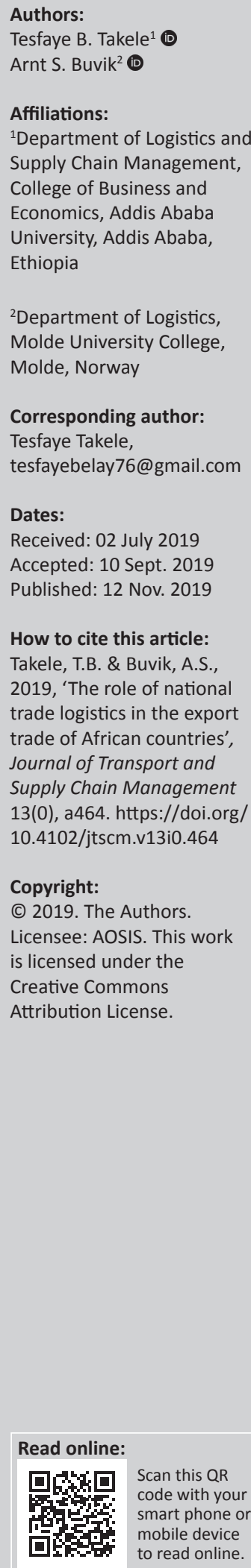

Background: This article critically examines the role of trade logistics in the exports of African countries. The performance of the trade logistics of African countries was analysed using the World Bank logistics performance index (LPI) and its components. The study was conducted based on the performance statistics of countries around the world in 2016.

Objectives: The aim of this study was to identify African countries' inefficient trade logistics areas based on LPI components for future improvement; and to investigate the relevance of trade logistics performance of African countries on export values in order to boost the region's merchandise export share in the global market.

Method: The methodological approach employed in this study is a combination of both descriptive and inferential data analysis. The African countries' logistics performance in international trade was summarised using LPI median values. The effect of the performance of trade logistics on exports was explored based on a gravity model of international trade. For the estimation, the Heckman selection approach was applied to incorporate zero bilateral trades.

Results: On average, African countries experience the lowest LPI score, particularly in terms of quality of trade and transport-related infrastructure, and customs and border clearance. A successful improvement in these areas would enhance African countries' supply chain deliveries including on-time delivery, tracking and tracing and international shipments in cross-border transactions.

Conclusion: The evidence from the gravity model estimates of this study suggests that an improvement in any of the LPI components can lead to significant growth in the export of African countries. This could then increase the African merchandise export share in global trade. The gravity model results also show that landlocked countries have lower trade flows than their coastal neighbours.

Keywords: African; logistics performance index; export; landlocked countries of Africa; global trade; gravity model.

\section{Introduction}

Following the Industrial Revolution, world trade has grown faster than the world's output of manufactured and primary products. The export of countries has become significantly larger except for the period between 1913 and 1950 as a result of the two world wars and the Great Depression (Ul Haque et al. 1995). Global trade has continued to grow rapidly. From 1951 to 2004 global trade of merchandise, including agricultural products, fuel, and mining and manufacturing products has grown on average by 5.9 per annum (World Trade Organization [WTO] 2005). Trade rise continued from 2003 to 2008, until the financial crisis. Then, the world trade rebounded in 2010 and 2011 (United Nations Conference on Trade and Developments 2017).

There are many plausible reasons for global trade growth. Technological advancement in transportation and communication, together with investment and population growth, have played a remarkable role. After the Second World War, political and economic cooperation between countries, with the aim of reducing barriers to cross-border trade, also played a pivotal role (WTO 2015). Efforts in reducing formal and informal barriers to cross-border trade have been made through international organisations such as WTO to create a free global market. Global cooperation efforts lead to a more integrated and interdependent global economy through the globalisation of production and markets (Hill 2008). The development of transport and communication technologies has been the main driver of global economic integration (World Economic Forum 2013). 
As $80 \%$ of world trade (by volume) and $70 \%$ (by value) is transported by maritime transport (UNCTAD 2012), another notable reason for the increase in global trade is the reduction in cost of international shipping during the second half of the 20th century. There was a substantial reduction in shipping cost because of the significant technological change in shipping, which includes the development of jet aircraft engines and containerisation (Hummels 2007). Based on bilateral trade flows between OECD countries, specific causes of average world trade growth and their respective level of contribution have been identified. These are income growth $(67 \%)$, tariff rate reduction and preferential trade agreement $(25 \%)$ and transportation cost reduction $(8 \%)$ (Baier \& Bergstrand 2001).

In the period between 1960 and 1990, the share of export as a percentage of gross domestic product (GDP) has increased from $12 \%$ to $20 \%$ in industrial countries, from $16 \%$ to $28 \%$ in middle-income countries and from $7 \%$ to $18 \%$ in low-income countries (Ul Haque et al. 1995). Between 1995 and 2011, world trade increase in volume and value was because of the increase in the contribution of global supply chains in the global economy, the entrance of new protagonists in global trade such as China and India and the diversification of export products (WTO 2015). However, trade in African countries did not increase as expected.

\section{Rationale for the study}

Trade is recognised as one of the means through which countries will achieve sustainable growth and poverty reduction in developing countries. The volume and variety of exports of Africa were relatively better in the late 1940s and early 1950s with 7.3\% (1948) and 6.5\% (1953) share in the world merchandise exports (WTO 2015). However, the share of African exports in the global market has declined to 4.3 in 1973 to 2.4 in 2003; and finally to 2.2 in 2016 (WTO 2015, 2017). From the 1970s until 2000, the exports of most African countries experienced stagnation because of political and economic crises (Kareem 2011).

Though there are several factors contributing to the decline of Africa's share in global trade, high trade transaction cost and quality of basic transport and communication infrastructure have a paramount contribution (Iwanow \& Kirkpatrick 2009). Trade logistics refers to a number of processes and services that are involved in delivering goods from one country to another. These include customs clearance and administration, transportation, tracking and tracing, international shipment management and information communications (Korinek \& Sourdin 2011). This study has emphasised trade logistics performances that are determined at a national level. An improved performance in trade logistics would increase the ability of companies in trading countries to respond to international orders at the right time with lower costs, in other words timely delivery will reduce inventory costs (Saslavsky \& Shepherd 2012).
The development of appropriate trade and transport facilitation policies requires having a better understanding of logistics performance at a national level over time (Rantasila \& Ojala 2012). Implementing the performance measurement of national level logistics is essential in improving the efficiency of logistics performance, infrastructure services and regulations (Rantasila \& Ojala 2012). The World Bank has been measuring trade logistics performance of countries since 2007 through its index. This measure is known as the logistics performance index (LPI). The LPI reveals the logistics performance of countries in international trade, aimed at identifying the challenges and opportunities of countries for improvement (Arvis et al. 2016). The LPI has two limitations: respondents of an LPI survey may not represent all logistics environments and landlocked countries and LPI might be affected by transit inefficiencies. Despite these limitations, LPI is a comprehensive measure of countries' logistics performance in international trade (Arvis et al. 2018).

In accordance with the 2016 LPI, the gap between the best- and the worst-performing countries is very big, with Germany being the best-performing (4.23) and Haiti being the worst-performing country (1.72). Improving trade logistics performance is vital in enhancing the trade competitiveness of countries. Inefficient logistics will raise the trading cost and undermine the potential to maximise international trade (Arvis et al. 2016).

The average score in the LPI for African countries during the year 2016 indicates that the region's countries have low performance, with an average score of 2.43 out of 5 (median). The LPI encourages further studies, particularly for countries whose trade logistics performance continues to be low (Arvis et al. 2010). This study is a logical extension of earlier studies conducted to investigate the effect of countries logistics performance on export. Based on gravity model estimates on the role of logistics in international trade for emerging regions - the Far East, Eastern Europe, Africa, the Middle East and South America - an improvement in any LPI components has a significant positive effect on increasing international trade for both exporting and importing countries (Martí, Puertas \& García 2014). Furthermore, it is necessary to examine the role of trade logistics in enhancing the international trade performance of African countries in much detail through identifying gaps.

Using the above facts, this research was conducted to investigate the role of a country's trade logistics performance on enhancing export, with specific emphasis on African countries. Accordingly, the major objectives of this study were: (1) to identify the region's inefficient trade logistics areas based on LPI components for future improvement, and (2) to investigate the relevance of trade logistics performance of African countries on export values in order to boost the region's merchandise export share in the global market. The findings of this study offer a rational support for policymakers concerning the importance of improving 
trade logistics performance to enhance the export competitiveness of countries.

\section{Literature review}

The increasing complexity of global business has offered an opportunity for logistics to play a pivotal role in determining the international trade performance of countries (Martí, Puertas \& García 2014). An improvement in trade logistics performance would significantly enhance international trade (Korinek \& Sourdin 2011; Martí et al. 2014; Saslavsky \& Shepherd 2012). According to LPI results in 2007 and 2010 among the countries that are at similar levels of per capital income, those with best logistics performance recorded an extra growth of $1 \%$ in gross domestic product and $2 \%$ in trade (Arvis et al. 2010). Improving performance on trade-related logistics such as infrastructure development, logistics service, port efficiency and information systems is critical to enhancing the performance of countries with regards to trading products on time and at a lower cost (Arvis et al. 2007). Time is a very important competitive factor in marketing and a barrier in trade. Lengthy export and import procedures may reduce a company's chances of entering into the export market for time-sensitive products, such as fashion cloth and consumer electronics. This will further affect the volume of trade (Nordås, Pinali \& Grosso 2006). Inadequate coverage and quality of infrastructure will affect trade competitiveness of countries by increasing the cost of doing business (Calderón \& Servén 2004).

Improvements in trade logistics performance will have a significant contribution in enhancing a country's international trade competitiveness (Martí et al. 2014). Investigating the logistics performance improvement of EU countries (2005-2010) using the World Bank LPI and its six dimensions reveals that trade logistics has a significant positive effect on bilateral trade flows. However, trade logistics is more important for countries that are exporting rather than countries that are importing (Puertas, Martí \& García 2013). Based on cross-country time-series data for 60 countries, Korinek and Sourdin's (2011) finding revealed that an improvement in trade logistics performance will enhance overall trade of countries at all levels of development.

\section{Landlocked countries of Africa}

Economists consider technological progress and access to market as engines of economic development. Technological innovations through research and development are very important to increase a country's productivity gains from specialisation. These gains gain root when producers have access to larger markets to sell their products and buy inputs (Hausmann 2001). Even if there is a reduction in tariff and institutional obstacles to cross-border investment and trade, the geography of economies plays an important role in shaping the distribution of variations in per capita income across countries (Redding \& Venables 2004).
Policy is not a primary problem for many poor countries in Africa, but geography is; many African countries are geographically handicapped: some countries are located far from seas while others are landlocked (Hausmann 2001). There are 16 landlocked countries in sub-Saharan Africa (UN-OHRLLS 2016), which together have a total population of about 300 million (World Bank 2016), that is, nearly 30\% of Africa's total population. Being landlocked means not having direct access to the sea, so the international trade of import and export for the country is dependent on its access to the sea through neighbouring transit countries (World Bank Group \& UN-OHRLLS 2014). Landlocked countries are dependent on political stability and the institutional and infrastructural quality of neighbouring transit countries to reach overseas markets (Portugal-Perez \& Wilson 2008).

Based on the United Nations 1982 Convention on the Law of Sea - Part X, landlocked countries shall obtain access to the sea through the territory of transit states by using all means of transport, such as railways and roads. This convention came into force on 16 November 1994. The convention stipulates that transit cargoes shall not be subject to any taxes, duties and other charges in the transit states. However, landlocked countries would pay for specific services with cargo flows and for use of a means of transport in transit states. Both countries, landlocked and transit, should agree on terms of services and payments (United Nations Convention on the Law of the Sea 1982).

Being landlocked does not necessarily lead to slow economic growth or poverty; however, in an economic context, being landlocked reduces connectivity and increases the cost of access to the sea (World Bank Group \& UN-OHRLLS 2014). MacKellar, Andreas and Wörz (2000) explore the impact of being landlocked on economic growth using data from a sample of 92 developing countries during the period 1980-1996. They estimate that landlocked developing countries have $1.5 \%$ lesser economic growth per year than coastal states. In terms of trading cost, landlocked developing countries have over 1.5 times higher trading cost than their corresponding coastal countries (World Bank Group \& UN-OHRLLS 2014). Likewise, based on empirical evidence from the 2005-2010 period, UN-OHRLLS estimated that the average development of landlocked developing countries was lower by $20 \%$ than it would be if they were not landlocked (UN-OHRLLS 2013).

Landlocked countries have a higher trading cost for administrative practices, documentation, terminal handling and inland transport (Portugal-Perez \& Wilson 2009). Landlocked countries are characterised by a higher cost per container, a larger number of documents and a longer time required to import or export compared to transit coastal countries (World Bank Group \& UN-OHRLLS 2014). The transport cost of landlocked countries is dependent on the cost of its transit country's transport infrastructure development; consequently, 'neighbours matter'. A transit country having a poor transport infrastructure to link to a port 
and having social, economic and political problems will worsen the problems of landlocked countries (Collier 2007). Evidence shows that the logistics costs of landlocked countries, other than transportation, constitute a very high percentage of their total sales (World Bank Group \& UN-OHRLLS 2014).

A lack of direct access to the sea is a large overall constraint for a country's international trade connectivity. There is persistent difference in logistics performance among countries in accordance with their ability to directly access the sea. The landlocked countries LPI score is lower than that of their corresponding coastal countries (Arvis et al. 2012). Landlocked countries in sub-Saharan Africa have experienced higher inland transport costs and time delays in moving export cargoes to seaports because of complex interactions with multiple policies and physical characteristics with their transit neighbours, a longer time for inland transport, a high level of uncertainty and low road density (Christ \& Ferrantino 2011).

\section{African exports to the global market}

In the 1960s, many had predicted Africa's bright future as many African countries came out of the shadow of colonialism (NEPAD 2012). African economies were growing during the period from the 1950s to the 1970s (Jerven 2017). Even though the external trade of most economies had shown growth, the global trade of Africa fell dramatically (Coe \& Hoffmaister 1999). As shown in Figure 1, the African share in the world merchandise export dropped dramatically from $7.3 \%$ in 1948 to $4.3 \%$ in 1973 and finally to $2.4 \%$ in 2003 . Accordingly, the African share in world trade was not only low but had experienced a dramatic fall.

Contrary to expectations, both political and economic issues started to deteriorate in the 1970s when the leaders of many African countries became dictators and autocrats (Collier \& Gunning 1999). After the 1970s, economic growth becoming challenging for Africa was partly due to unwise economic policies, a failure to make deep change on the economic structure, oil price shocks in the 1970s (Cooper 2019) and a decline in manufacturing (Economic Commission for Africa 2017).

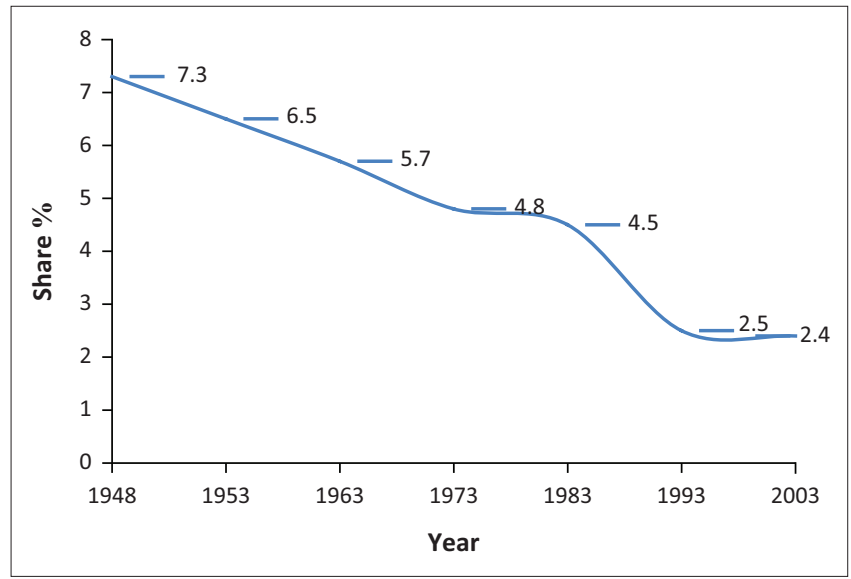

Source: Figure constructed based on data from WTO, 2005, International trade statistic 2005, World Trade Organization, Switzerland.

FIGURE 1: African merchandise export share of global export (1948-2003).
As shown in Figure 2, the African share of global merchandise export showed a minor improvement from $2.4 \%$ (2004) to $3.5 \%$ (2012). Despite some improvements in 2014, where Africa accounts for $3 \%$ of global export of merchandise, from 2012 onwards the decline in African trade rebounded and reached its lowest level of 2.2\% in 2016 (see Figure 2).

Various causes have been identified for Africa's low trade share in the global market. These include specialisation in primary products and low intra-regional trade (Siddiqi 2008; World Economic Forum 2013), poor infrastructure, low industrialisation and productivity, weak policies and geographical disadvantage (Siddiqi 2008). Africa's export is limited to a few types of primary commodities dominated by fuel and mining products. For instance, out of the total exports in 2014, agricultural products accounted for $11.5 \%$, fuels and mining products constituted $62.9 \%$ and manufacturing contributed 21.3\% (WTO 2015). Another major impediment to African trade performance is a high trading cost; in comparison to developing regions, subSaharan Africa remains the highest-cost region both in 1996 and 2010 (OECD/WTO 2015). The high cost of getting goods from and to borders and ports is limiting the region's gain from international trade (Donaldson, Jinhage \& Verhoogen 2017).

Harmonising customs procedures, tackling corruption and illegal practices prevailing at border and checkpoints in many African countries will significantly reduce trade costs (Barka 2012). It is necessary to transform Africa's export from primary commodities into diversified new products and new markets by improving product quality and export destinations (Nuwamanya 2012); increasing intra-Africa trade with the adoption of trade facilitation measures through the creation of the Continental Free Trade Agreement of Africa will boost the region's exports both at the global and country level (Mevel \& Karingi 2012). Exporting new products to neighbouring markets will increase products and market experience. Then, new and

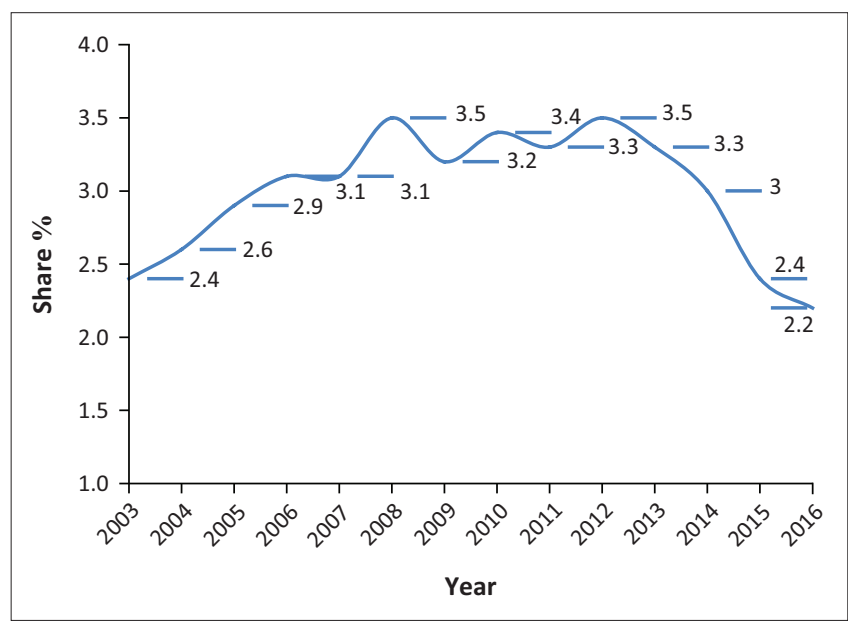

Source: Figure constructed based on data from WTO, 2005, International trade statistics 2005, World Trade Organization, Switzerland; WTO, 2015, International trade statistics 2015 , World Trade Organization, Switzerland; WTO, 2017, World trade statistical review 2017, World Trade Organization, Geneva.

FIGURE 2: African merchandise export's share of global export (2003-2016). 
old products will be exported to the rest of the world (Nuwamanya 2012).

Relative to other regions, intra-regional trade is low in Africa, it accounted for $17.7 \%$ of the region's total merchandise exports in 2014. On the other hand, trade within a region plays a major role in other regions of the world, for instance, Europe 68.5\%, Asia 52.3\% and North America 50.2\% during 2014 (WTO 2015). The bottlenecks for regional trade integration of Africa include inadequate infrastructure (particularly in transportation and energy), poor institutional and regulatory environment and lack of full commitment in implementing regional integration efforts (World Economic Forum 2013). Some African countries like Ethiopia, Burundi, Malawi and Côte d'Ivoire are highly dependent on agricultural exports. In contrast, African countries import agricultural products from regions other than their own because of poor intra-regional integration and high transaction costs (World Economic Forum 2013).

\section{Logistics performance index}

Comprehensive and multidimensional national level logistics performance indicators are critical in preparing and implementing effective policies. In this regard, the World Bank developed a sound and comprehensive index that measures a particular country's logistics efficiency in international trade and has implemented it since 2007. This measure is known as the LPI. The LPI has facilitated numerous policy reforms by providing relevant information for policymakers, private executives and any other stakeholders on a country's abilities to manage logistics operations in the global business environment. Logistics performance indicators are revised based on theoretical and empirical research findings and practical experience of logistics professionals engaged in global logistics. Generally, the LPI measures a country's trade logistics performance (Arvis et al. 2007, 2016).

The LPI was developed based on a worldwide survey of companies that are responsible for transporting goods and facilitating trade across borders (Arvis et al. 2016). The LPI uses a standard questionnaire with two parts: international and domestic. For the international part, respondents (multinational freight forwarders and main express carriers) assess a country's national logistics performance in six dimensions that capture the most important aspects of the logistics environment. The international LPI provides a clear understanding of the national logistics performance of countries around the world on cross-border trade and transport facilitation, infrastructure planning and development, supply chain reliability and service quality.

International LPI provides a qualitative evaluation of a country using a scale of 1-5 for each dimension (Arvis et al. 2010). The lowest score refers to the worst performance and the highest score refers to the best performance. The six dimensions of the LPI are classified into two types: input and outcome. Customs, infrastructure and service quality are areas for policy regulations (inputs). Timelines, international shipments, and tracking and tracing are outcomes represented by service delivery performance (Arvis et al. 2016). Each of the World Bank LPI dimensions are summarised as follows:

- Customs: Analyse the efficiency of customs clearance and border management, such as speed, simplicity and predictability of formality.

- Infrastructure: Refers to the quality of trade and transportrelated infrastructure that includes roads, railways, ports, airports, warehouses, intermodal facilities, and information and communication technologies.

- International shipments: Analyse the flow of goods with regards to the ease of arranging competitively priced international shipments.

- Service quality: Assess the competence and quality of logistics service, customs brokerage, and tracking and forwarding. Logistics service quality is critical in ensuring reliable supply chain to producers and exporters.

- Tracking and tracing: Refers to the ability to track and trace consignments.

- Timeliness: Analyse the frequency with which shipments reach consignees within scheduled or expected delivery times (Arvis et al. 2016). Generally, LPI scores capture freight forwarders perception of performance on a country's efficiency of trade logistics. It might not fully reflect the changes in the country. Accordingly, LPI scores should not be overvalued (Arvis et al. 2012).

\section{Research methodology}

\section{Nature and source of data}

This research examines the effect of trade logistics performance on countries' export. As a result, the export of countries is a dependent variable. Export is measured by the monetary value of the export of African countries for aggregated merchandise trade with the rest of the world in bilateral trade flows. Bilateral export value comprises all commodities classified under the Standard International Trade Classification (SITC) Revision 1 (total of all SITC Rev. 1 commodities, Export). Trade logistics performance of countries is an independent variable, measured by LPI.

This study was carried out based on the LPI result of countries in 2016. As a result, the study population includes countries that were part of the World Bank 2016 LPI survey. Data on gravity model variables: GDP, geographical distance and history were taken from the same year with the LPI survey. A descriptive analysis was carried out incorporating all African countries (45) that were part of the 2016 LPI survey. The international trade gravity model was applied to explore the association between trade logistics performance and export. In this study, source (exporting) countries were African countries. The gravity data set for this study was gathered from 18 sources and 91 destinations countries. As a result, the gravity data set comprises $18 \times 91=1638$ bilateral trade flows carried out in 2016. Countries were selected purposefully. African countries that are included in the 2016 LPI and having bilateral trade 
with at least 95 countries were selected for the study. On the destination side, all countries that were part of the 2016 LPI were selected as importing countries (destination). However, African countries were not included on the destination side. A summary of data sources for the study variables is presented in Table 1 .

\section{Gravity model}

The gravity equation has been employed for a long period, consistently explaining trade flows from origin $i$ to destination $j$ using log-linear equations (Bergstrand 1985). As cited by Sanso, Cuairan and Sanz (1993), the first formulations of the gravity equation are found in the works of Tinbergen (1962), Poyhonen (1963) and Pulliainen (1963). In its basic form, the gravity equation is applied to explain trade flows between pairs of countries as a function of income, distance and distinctive factors such as common language and common border that will facilitate or reduce bilateral trade flows (Fratianni 2007). The assumptions made in the basic gravity model are that traded goods between countries $i$ and $j$ are a function of the trading income and population of the countries; goods are differentiated by place of origin, and transport cost is represented by distance with an approximation (Anderson 1979).

The gravity model of international trade was proposed based on Newton's law of universal gravitation, which states that larger objects are closer to each other, so they have a greater force of gravity between them. Likewise, trade that takes place between countries, the GDP of trading countries is used as a substitute for the mass of two objects (Feenstra 2015). Therefore, the amount of trade between countries is directly proportional to the countries' economic size. On the other hand, trading costs will reduce bilateral trade flows (Head 2003). In a broad context, trading cost includes all costs incurred in delivering goods from local production areas to foreign customers, such as tariffs, information costs, legal and regulatory costs, contract enforcement costs and costs associated with the use of different currencies (Anderson \& Van Wincoop 2004).

In the gravity equation, bilateral trade cost is approximated with bilateral physical distance, common language, common legal tradition, adjacency and preferential trade membership (Anderson \& Van Wincoop 2004). Distance between country $i$ and $j$ reflects transport cost (Bergstrand 1985). Accordingly, additional dummy variables like historical background

TABLE 1: Data source.

\begin{tabular}{|c|c|}
\hline Variables & Data source: Database \\
\hline Export value & $\begin{array}{l}\text { The United Nations Commodity Trade Statistics Database } \\
\text { (UN Comtrade), accessed February, 2018. https://comtrade. } \\
\text { un.org/data/ }\end{array}$ \\
\hline LPI & $\begin{array}{l}\text { World Bank Group: Aggregated LPI 2012-2018, accessed February, } \\
\text { 2018. http://lpi.worldbank.org/ }\end{array}$ \\
\hline GDP, population & $\begin{array}{l}\text { World Bank Group: World Bank Open Data, accessed February, } \\
\text { 2018. http://data.worldbank.org/ }\end{array}$ \\
\hline $\begin{array}{l}\text { Distance, } \\
\text { language, colony, } \\
\text { landlockedness }\end{array}$ & $\begin{array}{l}\text { Centre d'Etudes Prospectives et d'Informations Internationales } \\
\text { (CEPII): Geography, accessed February, 2018. http://www.cepii.fr/ } \\
\text { cepii/en/bdd_modele/bdd.asp }\end{array}$ \\
\hline
\end{tabular}

were included in the basic gravity equations as proxies for trade cost (Bacchetta et al. 2012). Dummy variables include common language, common land border, common colonisers and colonial relationship (Fratianni 2007). Colonial relationship creates a common business culture and official language, which are important to capture information costs (Bacchetta et al. 2012).

The gravity model was applied to estimate the value of bilateral trade between countries. In addition to core variables such as GDP and distance, gravity equations can contain other variables that influence bilateral trade flows, such as trade policy and institutional variables (Portugal-Perez \& Wilson 2009). Numerous researchers (e.g. Freund \& Rocha 2010; Hausman, Lee \& Subramanian 2005; Portugal-Perez \& Wilson 2009) have applied the gravity model to explore the effect of logistics on bilateral trade flows.

Bilateral trade gravity equations can be estimated for either a panel of countries or a cross-section of countries (Bacchetta et al. 2012). Cross-section data are data on one or more variables which are collected for several sample units at the same points in time (Gujarati 2003). A study by Puertas et al. (2013) has explored the importance of trade logistics performance on export competitiveness of European countries by developing several gravity equations using LPI components as proxy variables for trade facilitation (Puertas et al. 2013). Having the above theoretical and empirical evidence, the gravity model of international trade is considered a fitting model for this research. The gravity model equations used in this study are presented as follows:

$$
\begin{aligned}
\log \left(Y_{i j}\right)= & \beta_{0}+\beta_{1} \log \left(D_{i j}\right)+\beta_{2} \log \left(G D P_{i}\right) \\
& +\beta_{3} \log \left(G D P_{j}\right)+\beta_{4} \log \left(L P I_{i}\right) \\
& +\beta_{5} \log \left(L P I_{j}\right)+\beta_{A}(W)+U_{i j}
\end{aligned}
$$

Where

$Y_{i j}=$ Value of export from country $i$ to country $j$

$i=$ Exporting countries

$j=$ Importing countries

$D_{i j}=$ Geographical distance between trading countries

$\mathrm{GDP}_{i}=$ Gross domestic product of exporting countries

$\operatorname{GDP}_{j}=$ Gross domestic product of importing countries

LPI $_{i}=$ LPI of exporting countries

$\mathrm{LPI}_{j}=\mathrm{LPI}$ of importing countries

$W=$ Set of dummy variables (official language, colony, being landlocked)

$U_{i j}=$ Error term

According to the above equation, the value of exports from country $i$ to country $j$ is a function of the economic size of exporting and importing countries, distance between capital cities of trading countries and logistics performance of both exporting and importing countries. Dummy variables for official language and colonial history were used as a proxy for trade cost. A dummy variable for lack of direct access to the sea (being landlocked) was included to investigate the effect of being landlocked. In modelling gravity equations 
and conducting estimation, it is recommended to develop a separate equation for each LPI component to avoid multicollinearity among LPI components (Puertas et al. 2013). As a result, separate equations were derived for each LPI component as follows:

$$
\begin{aligned}
\log \left(Y_{i j}\right)= & \beta_{0}+\beta_{1} \log \left(D_{i j}\right)+\beta_{2} \log \left(G D P_{i}\right)+\beta_{3} \log \left(G D P_{j}\right) \\
& +\beta_{4} \log \left(\text { Customs }_{i}\right)+\beta_{5} \log \left(\text { Customs }_{j}\right) \\
& +\beta_{A}(W)+U_{i j}
\end{aligned}
$$

$\log \left(Y_{i j}\right)=\beta_{0}+\beta_{1} \log \left(D_{i j}\right)+\beta_{2} \log \left(G D P_{i}\right)$

$+\beta_{3} \log \left(G D P_{j}\right)+\beta_{4} \log \left(\right.$ Infrastructure $\left._{i}\right)$

$+\beta_{5} \log \left(\right.$ Infrastructure $\left._{j}\right)+\beta_{A}(W)+U_{i j}$

[Eqn 3]

$\log \left(Y_{i j}\right)=\beta_{0}+\beta_{1} \log \left(D_{i j}\right)+\beta_{2} \log \left(G D P_{i}\right)$

$+\beta_{3} \log \left(G D P_{j}\right)+\beta_{4} \log \left(\right.$ Shipments $\left._{i}\right)$

$+\beta_{5} \log \left(\right.$ Shipments $\left._{j}\right)+\beta_{A}(W)+U_{i j}$

[Eqn 4]

$\log \left(Y_{i j}\right)=\beta_{0}+\beta_{1} \log \left(D_{i j}\right)+\beta_{2} \log \left(G D P_{i}\right)$

$+\beta_{3} \log \left(G D P_{j}\right)+\beta_{4} \log \left(\right.$ Quality $\left._{i}\right)$

$+\beta_{5} \log \left(\right.$ Quality $\left._{j}\right)+\beta_{A}(W)+U_{i j}$

[Eqn 5]

$\log \left(Y_{i j}\right)=\beta_{0}+\beta_{1} \log \left(D_{i j}\right)+\beta_{2} \log \left(G D P_{i}\right)$

$+\beta_{3} \log \left(G D P_{j}\right)+\beta_{4} \log \left(\right.$ Tracking $\left._{i}\right)$

$+\beta_{5} \log \left(\right.$ Tracking $\left._{j}\right)+\beta_{A}(W)+U_{i j}$

[Eqn 6]

$\log \left(Y_{i j}\right)=\beta_{0}+\beta_{1} \log \left(D_{i j}\right)+\beta_{2} \log \left(G D P_{i}\right)$

$+\beta_{3} \log \left(G D P_{j}\right)+\beta_{4} \log \left(\right.$ Timeliness $\left._{i}\right)$

$+\beta_{5} \log \left(\right.$ Timeliness $\left._{j}\right)+\beta_{A}(W)+U_{i j}$

[Eqn 7]

In international trade gravity model estimation, it is common to have zero reported bilateral trade between countries in year $t$, even in aggregated trade data (Shepherd 2013a). Zero bilateral trade will be dropped from estimation in Ordinary least squares (OLS), which leads to sample selection bias (Santos Silva \& Tenreyro 2006). To address the selection bias that results from zero bilateral trade, the Heckman model is proposed (Heckman 1979; Shepherd 2013a). This research has employed a Heckman sample selection to incorporate zero bilateral trades. With regard to the gravity model statistical test, this study variance inflation factor and correlation matrix test results revealed the absence of multicollinearity between variables. In addition, the probability plot and kernel density estimation show that the study equations confirmed that the data set is normally distributed.

However, test results indicate the presence of heteroscedasticity in this research model. The gravity model deals with observations that are obviously heterogeneous for several reasons. The assumption of homoscedasticity of the error term is likely to be violated (Bacchetta et al. 2012). Effective remediation of heteroscedasticity in gravity context is to use a robust option. A robust approach produces standard errors that are robust to arbitrary patterns of heteroscedasticity in the data (Bacchetta et al. 2012; Shepherd 2013a). The robust option was employed in this research model. Consequently, the equations of this study will precisely explain trade flows of African countries to the rest of the world.

\section{Ethical considerations}

This article followed all ethical standards for research without direct contact with human or animal subjects.

\section{Results and analysis}

This research aimed at investigating the importance of trade logistics performance of Africa in enhancing the region's international trade performance. This section comprises results, an analysis and discussions of the study.

\section{Logistics performance index of Africa}

Based on the World Bank's LPI, the overall trade logistics performance of Africa is low. With regard to each country's performance, South Africa has a relatively good overall logistics performance (3.78, maximum score). On the other hand, Somalia has a very low overall logistics performance $(1.75$, minimum score). As a result of such extreme values, the median is employed to summarise the LPI of African countries under each component. On average, African countries score less than 2.5 in five of the six LPI components, except for on-time delivery in the 2016 LPI.

Figure 3 presents the average trade logistics performance of 45 African countries during the year 2016. The LPI dimensions have been depicted in a descending order with their respective scores (see Figure 3). The lowest performance was observed to be in terms of the quality of trade and transport-related infrastructure (railways, roads, ports, warehouses, intermodal facilities, ICT) and customs and border management. Africa has also experienced low performance in terms of ability to track and trace consignments, competence and quality of logistics service, and ease of arranging competitively priced international shipments. However, the region has relative good trade logistics performance in terms of on-time delivery

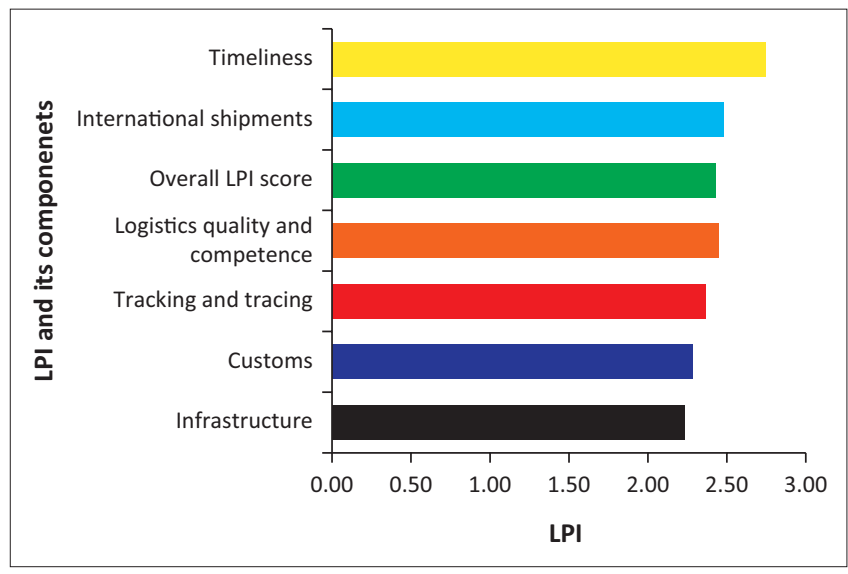

Source: Figure constructed based on data from World Bank Group, 2016, Aggregated Logistics Performance index 2012-2018. https://lpi.worldbank.org/.

$\mathrm{LPI}$, logistics performance index.

FIGURE 3: Logistics performance index of Africa. 
of shipments. The evidence from this study suggests that African countries should improve their trade logistics performance in all LPI dimensions.

There are various possible causes for the low performance of Africa in terms of quality of trade and transport-related infrastructure. These include inadequate and low-quality transport and related infrastructure (World Economic Forum 2013). In many parts of Africa, the road quality is below international standards, for example, only $29.7 \%$ of Africa's road network is paved and many African highways have unwarranted checkpoints along transit corridors which result in more delays (Kingombe 2014). In sub-Saharan Africa, the accumulation of infrastructure assets and quality of service delivery are weak relative to these countries' spending (Ajakaiye \& Ncube 2010).

It is essential for African countries to develop adequate and efficient infrastructure to enhance the productivity of African economies in global trade (World Economic Forum 2013). Logistics infrastructure developments should incorporate both hard and soft infrastructure. Hard infrastructure involving ports, airports, roads and rail links are primary points for trade facilitation. Furthermore, soft infrastructure such as transport regulations, customs and border procedures can play more than a secondary role (Shepherd 2013b). Consequently, the improvement in trade and transport-related infrastructure will improve other trade logistics areas and subsequently increase overall logistics performance.

Africa's low performance in customs clearance and border management is partly because of burdened bureaucratic procedures, inefficient communications between agencies, lack of transparency, corruption at border administrations (World Economic Forum 2013), excessive physical inspection and poor regional cooperation (McLinden et al. 2011). Complex border procedures and bureaucratic bottlenecks reduce the ability of countries to reach global markets (World Bank \& International Finance Corporation 2013). A sound implementation of border management reform that encompasses all relevant stakeholders would cut the red tape and unnecessary physical inspections (Arvis et al. 2012).

Further improvement in terms of customs efficiency can be obtained through computerisations of customs offices and automation of customs procedures. All automated customs offices should be connected with one another (Ojala \& Çelebi 2015). To reduce cumbersome procedures, duplication of duties and uncertain delays, African countries should implement one-stop border posts, where customs operations are carried out at only one side of the border but comply with the laws of both countries. This can be implemented by regional groups (Barka 2012). It is also important for African countries to establish a single window system so that clients provide all the required information at one time (McLinden et al. 2011).

\section{The effect of trade logistics on exports}

Identifying a strategic role that national trade logistics performance will have on regional trade competitiveness requires studying the effect of national trade logistics performance on the bilateral trade flows of the countries in the region with their trading partners in other regions. The gravity model estimation results for each equation are presented in Table 2. All explanatory variables have a statistically significant positive effect as expected. The model produces standard errors that are robust to arbitrary patterns of heteroscedasticity. Regarding the relationship between selection and outcome equations, the Heckman model output test of the null hypothesis ' $r$ ho is equal to zero' is not significant. This indicates error terms of selection and outcome equations are uncorrelated. As a result, sample selection does not create bias (Shepherd 2013a).

Bilateral trade flows are inversely proportional to the distance between countries (Dhar \& Panagariya 1994). In accordance with empirical analysis of 1467 distance effects estimated in 103 papers by Disdier and Head (2008), the negative impact of distance on bilateral trade flows began to rise in the 1950s and has remained persistent with a mean elasticity of 0.9 . Though the effects of distance on international trade have reduced over time (Bleaney \& Neaves 2013), Magerman, Studnicka and Van Hove (2015) confirm that significantly negative effects of distance on bilateral trade flows remained over time. In this study, the coefficients on geographical distance were found to be negative with a high level of significance. This implies that countries with greater geographical distance will trade less because of higher transportation costs. In contrast, geographical proximity will tend to boost trade between countries. In terms of economic size, GDPs of both importing and exporting countries have a significant positive effect on bilateral trade flows. An increase in the exporter's and importer's GDP will increase bilateral trade flows. This implies that countries with bigger economies will trade more.

In addition to distance, a common official language and colonial relationships reduce trade costs, for example, costs of information search are reduced. Countries with a common official language and colonial ties are more likely to have similar business practices. Firms want partners that are working in countries with a similar business environment (Bacchetta et al. 2012). This research finding shows that countries which share a common official language have higher trade flows than those that do not, with a lower significance level. It is somewhat surprising to find in this study that colonial ties do not have a statistically significant effect on bilateral trade flows. A study conducted by Head, Mayer and Ries (2010), covering bilateral trade flow from 1948 to 2006, had shown that trade between colonisers and their earlier colonies had reduced tremendously. Hostile separation resulted in a large, immediate reduction in trade. In addition, unobserved country and country pair observations may 
TABLE 2: Effect of logistics performance index components on export.

\begin{tabular}{|c|c|c|c|c|c|c|c|}
\hline Trade & Eqn (1) & Eqn (2) & Eqn (3) & Eqn (4) & Eqn (5) & Eqn (6) & Eqn (7) \\
\hline Distance & $-1.663^{* * *}$ & $-1.787^{* * *}$ & $-1.621 * * *$ & $-1.648 * p^{*}{ }^{*}$ & $-1.509 * * *$ & $-1.634 * * *$ & $-1.577^{* * *}$ \\
\hline GDP exporter & $0.866 * * *$ & $0.911 * * *$ & $0.977 * * *$ & $0.8103 * * *$ & $0.786 * * *$ & $0.835^{* * *}$ & $0.991 * * *$ \\
\hline GDP importer & $1.029 * * *$ & $1.038 * * *$ & $1.010 * * *$ & $1.065 * * *$ & $0.985 * * *$ & $1.030 * * *$ & $1.065 * * *$ \\
\hline LPI exporter & $6.793 * * *$ & - & - & - & - & - & - \\
\hline LPI importer & $3.789 * * *$ & - & - & - & - & - & - \\
\hline Customs exporter & - & $3.725 * * *$ & - & - & - & - & - \\
\hline Infrastructure exporter & - & - & $6.752 * * *$ & - & - & - & - \\
\hline Infrastructure importer & - & - & $3.009 * * *$ & - & - & - & - \\
\hline Shipments exporter & - & - & - & $6.496 * * *$ & - & - & - \\
\hline Shipments importer & - & - & - & $3.678 * * *$ & - & - & - \\
\hline Quality exporter & - & - & - & - & $6.347 * * *$ & - & - \\
\hline Quality importer & - & - & - & - & $3.586 * * *$ & - & - \\
\hline Tracking exporter & - & - & - & - & - & $5.259 * * *$ & - \\
\hline Timeliness exporter & - & - & - & - & - & - & $5.891 * * *$ \\
\hline Timeliness importer & - & - & - & - & - & - & $4.330 * * *$ \\
\hline Official language & $0.368 *$ & $0.388 *$ & 0.315 & $0.457 * *$ & $0.370 *$ & $0.381 *$ & $0.4134 * *$ \\
\hline Colony & 0.6104 & 0.673 & 0.611 & 0.730 & 0.704 & 0.678 & 0.6180 \\
\hline Landlocked & $-1.061^{* * *}$ & $-0.999 * * *$ & $-1.066 * * *$ & $-1.078^{* * *}$ & $-1.014^{* * *}$ & $-0.938 * * *$ & $-1.010 * * *$ \\
\hline Constant & $23.857 * * *$ & $19.300 * * *$ & $24.129 * * *$ & $23.537 * * *$ & $21.762 * * *$ & $21.071 * * *$ & $28.660 * * *$ \\
\hline
\end{tabular}

Note: $*, * *$ and $* * *$ denote test statistical significance at $10 \%, 5 \%$ and $1 \%$ levels, respectively.

LPI, logistics performance index; GDP, gross domestic product; Eqn, equation.

contribute to such effects. However, a lack of direct access to the sea or being landlocked has a statistically significant negative effect on exports. Relative to corresponding coastal countries, landlocked countries have lower trade. It is suggested that landlocked countries should implement different trade facilitation strategies.

Overall, logistics performance displays that a country's LPI has a significant positive effect on export. However, exportLPI coefficient $\left(b_{4}=6.8, p<0.01\right)$ is higher than import-LPI coefficient $\left(b_{5}=3.8, p<0.01\right)$. Therefore, an improvement in trade logistics performance of both exporters and importers will have a significant effect on increasing bilateral export flows. Furthermore, an improvement in logistics performance is more relevant for exporting countries than it is for importing countries. Evidence from each LPI component confirmed that there is a positive effect on export in bilateral trade flows.

The results obtained from regression estimates under each LPI component prove the relevance of all LPI dimensions on export. All LPI components have positive effects on bilateral trade flows with a high level of significance $(p<0.01)$. These components are the efficiency of customs clearance and border management, quality of trade and transport-related infrastructure, availability of competitively priced international shipments, competence and quality of logistics service, ability of tracking and tracing shipments, and frequencies with which shipments arrive on time. Trade logistics performance of exporting and importing countries under each LPI component confirmed that enhancing trade logistics performance is important in increasing export in bilateral trade flows. Among export-LPI components, trade and transport-related infrastructure development, international shipments, and competence and quality of logistics service have the strongest effect on the export of African countries.

\section{Conclusion}

This research aimed at investigating the strategic role of trade logistics in reviving Africa's export in the global market. This study intended to show the main inefficiencies of trade logistics for the regulators of African countries. The major impediments of trade logistics performance for African countries include a lack of logistics infrastructure development and customs and border clearance. A reasonable approach to improve the logistics performance of Africa in international trade should begin with logistics infrastructure development such as ports, railways, roads and intermodal facilities. Mbekeani (2010) pinpointed that transport infrastructure services of African countries could be improved through better and safe roads, efficient and safe ports and improved and maintained transport assets.

For some African countries, it is estimated that an improvement in trade logistics is more important than substantial cuts in tariff barriers (Portugal-Perez \& Wilson 2008). This study has substantiated the relevance of trade logistics in enhancing the international trade of African countries. Based on the international trade gravity model, the results of this research indicate that improvements in the LPI components have a positive effect on export. An implication of this is that an improvement in logistics infrastructure quality, customs clearance and logistics service competencies will enhance supply chain deliveries of African countries in terms of ontime delivery of shipments, ease of arranging competitively priced international shipments, and high-level tracking and tracing consignments. As a result, African countries should improve their trade logistics performance to increase their supply chain reliability internationally. This will enhance Africa's merchandise export and maximise the region's trade share in the global market. 
There are 16 landlocked countries in sub-Saharan Africa. Being geographically landlocked has a negative effect on export. Accordingly, landlocked African countries have export volumes that are lower than those of their corresponding coastal neighbours. This geographical disadvantage can be reduced through integrated development strategies that could be implemented by both coastal and landlocked countries (Collier 2007). This includes encouraging coastal neighbours to have better policies (Collier 2007), ensuring efficient hinterland connections through regional integration, and improving the availability and quality of logistics infrastructure for example ports, roads, railways, intermodal facilities and border checkpoints (World Bank Group \& UN-OHRLLS 2014).

Landlocked countries are likely to expand their trade in goods that can be transported by air (Korinek and Sourdin 2011). These products include vegetables, fruits, cut flowers, freshwater fish and meat as well as time-sensitive, high-value goods such as electronic components for the computer industry (World Bank Group \& UN-OHRLLS 2014). Air transportation can be expanded through low-cost air transport service provider companies (Collier 2007). Since over $80 \%$ of the world's merchandise trade is carried out by sea (UNCTAD 2015), regional trade facilitation by sea is necessary to enhance the international trade of landlocked countries (Korinek and Sourdin 2011).

\section{Future research direction}

This study gravity model finding explains the strategic role of trade logistics in enhancing Africa's export to the global market. The descriptive analysis evidence shows that African countries remain low performers in trade logistics performance measures. The implication of this research finding suggests further research needs to be conducted to investigate the root causes for the lowest LPI score of African countries, particularly in terms of trade and transport-related infrastructure development, and customs and border clearance.

\section{Acknowledgements}

This study was conducted as part of T.B.T.'s MSc in Logistics studies when he was studying at the Molde University College, Specialised University in Logistics.

\section{Competing interests}

The authors have declared that no competing interests exist.

\section{Authors' contributions}

T.B.T. was the main researcher of this article with A.S.B. as advisor. A.S.B. made a significant contribution by giving proper guidance, improving the study and providing all the necessary support.

\section{Funding information}

T.B.T. studied at the Molde University College under the Norwegian Quota Scheme Scholarship.

\section{Data availability statement}

All data are collected from public databases such as the World Bank data. Data will be made available, as required.

\section{Disclaimer}

The views expressed in this article are those of the authors and do not necessarily reflect the official policy or position of any organisation.

\section{References}

Anderson, J.E., 1979, 'A theoretical foundation for the gravity equation', The American Economic Review 69(1), 106-116.

Anderson, J.E. \& Van Wincoop, E., 2004, 'Trade costs', Journal of Economic Literature 42(3), 691-751. https://doi.org/10.1257/0022051042177649

Arvis, J.-F., Mustra, M.A., Ojala, L., Shepherd, B. \& Saslavsky, D., 2010, Connecting to compete 2010 trade logistics in the global economy: The logistics performance index and its indicators, World Bank, Washington, DC.

Arvis, J.-F., Mustra, M.A., Ojala, L., Shepherd, B. \& Saslavsky, D., 2012, Connecting to compete 2012 trade logistics in the global economy: The logistics performance index and its indicators, World Bank, Washington, DC.

Arvis, J.-F., Mustra, M.A., Panzer, J., Ojala, L. \& Naula, T., 2007, Connecting to compete: Trade logistics in the global economy. The logistics performance index and its indicators, World Bank, Washington, DC.

Arvis, J.-F., Ojala, L., Wiederer, C., Shepherd, B., Raj, A., Dairabayeva, K. et al., 2018, Connecting to compete 2016 trade logistics in the global economy: The logistics performance index and its indicators, World Bank, Washington, DC.

Arvis, J.-F., Saslavsky, D., Ojala, L., Shepherd, B., Busch, C., Raj, A. et al., 2016, Connecting to compete 2016 trade logistics in the global economy: The logistics performance index and its indicators, World Bank, Washington, DC.

Bacchetta, M., Beverelli, C., Cadot, O., Fugazza, M., Grether, J.-M., Helble, M. et al., 2012, A practical guide to trade policy analysis, World Trade Organization, United Nations.

Baier, S.L. \& Bergstrand, J.H., 2001, 'The growth of world trade: Tariffs, transport costs, and income similarity', Journal of International Economics 53(1), 1-27. https:// doi.org/10.1016/S0022-1996(00)00060-X

Barka, H.B., 2012, 'Border posts, checkpoints, and Intra-African trade: Challenges and solutions', OPEV Newsletter 2012, pp. 1-18.

Bergstrand, J.H., 1985, 'The gravity equation in international trade: Some microeconomic foundations and empirical evidence', The Review of Economics and Statistics 68(3), 474-481. https://doi.org/10.2307/1925976

Bleaney, M. \& Neaves, A.S., 2013, Declining distance effects in international trade Some country-level evidence. The World Economy 36(8), John Wiley \& Sons Ltd.

Calderón, C. \& Servén, L., 2004. The effects of infrastructure development on growth and income distribution. World Bank, Washington, DC.

Christ, N. \& Ferrantino, M.J., 2011, 'Land transport for export: The effects of cost, time, and uncertainty in sub-Saharan Africa', World Development 39(10), 1749-1759. https://doi.org/10.1016/j.worlddev.2011.04.028

Coe, D.T. \& Hoffmaister, A.W., 1999, 'North-South trade: Is Africa unusual?', Journal of African Economies 8(2), 228-256.

Collier, P., 2007, The bottom billion: Why the poorest countries are failing and what can be done about it, Oxford University Press, New York.

Collier, P. \& Gunning, J.W., 1999, 'Why has Africa grown slowly?', Journal of Economic Perspectives 13(3), 3-22. https://doi.org/10.1257/jep.13.3.3

Cooper, F., 2019, Africa since 1940: The past of the present. Vol. 13, Cambridge University Press, New York.

Dhar, S. \& Panagariya, A., 1994, Is East Asia less open than North America and the European economic community? No. International Economics Department International Trade Division, World Bank, Washington, DC.

Disdier, A.-C. \& Head, K., 2008, 'The puzzling persistence of the distance effect on bilateral trade', The Review of Economics and Statistics 90(1), 37-48. https://doi. org/10.1162/rest.90.1.37

Donaldson, D., Jinhage, A. \& Verhoogen, E., 2017, Beyond borders: Making transport work for African trade. IGC Growth Brief Series, 9.

Feenstra, R.C., 2015, Advanced international trade: Theory and evidence, 2nd edn., Princeton University Press, United States.

Fratianni, M., n.d., The gravity equation in international trade, in handbook of international business, 2nd edn, Oxford University Press, Forthcoming. Available at SSRN: https://ssrn.com/abstract=1013348.

Freund, C. \& Rocha, N., 2010, What constrains Africa's exports?. Staff Working Paper ERSD-2010-07. Development Economic Research Group, World Bank.

Economic Commission for Africa, 2017, Economic report on Africa 2017: Urbanization and industrializaton for Africa's transformaton, United Nations, Addis Ababa, Ethiopia. 
Gujarati, D.N., 2003, Basic econometrics, 4th edn., McGraw-Hill, New York.

Hausman, W.H., Lee, H.L. \& Subramanian, U., 2005, Global logistics indicators, supply chain metrics, and bilateral trade patterns, World Bank Policy Research Workin Paper no. 3773. World Bank.

Hausmann, R., 2001, 'Prisoners of geography', Foreign Policy 122, 44-53. https://doi. org/10.2307/3183225

Head, K., 2003, 'Gravity for beginners', Notes for University of British Columbia, viewed 18 October 2019, from https://vi.unctad.org/tda/background/Introduction $\% 20$ to $\% 20$ Gravity $\% 20$ Models/gravity.pdf.

Head, K., Mayer, T. \& Ries, J., 2010, 'The erosion of colonial trade linkages afte independence', Journal of International Economics 81(1), 1-14. https://doi. org/10.1016/j.jinteco.2010.01.002

Heckman, J.J., 1979, 'Sample selection bias as a specification error', Econometrica 47(1), 153-161. https://doi.org/10.2307/1912352

Hill, C.W., 2008, Global business today, 5th edn., McGraw-Hill Education, New York.

Hummels, D., 2007, 'Transportation costs and international trade in the second era of globalization', The Journal of Economic Perspectives 21(1), 131-154. https://doi. org/10.1257/jep.21.3.131

Iwanow, T. \& Kirkpatrick, C., 2009, 'Trade facilitation and manufactured exports: Is Africa different?,' World Development 37(6), 1039-1050. https://doi.org/10.1016/j. worlddev.2008.09.014

Jerven, M., 2017, Africa growing? Past, present and future, European Union Institute for Security Studies (EUISS), Paris.

Kareem, O.I., 2011, 'The European Union trade policies and Africa's exports', World Economics 12(2), 54

Kingombe, C., 2014, 'Hard and soft infrastructure development in Africa', Multi-year expert meeting on transport, trade logistics and trade facilitation second session Trade facilitation rules as a trade enabler: Options and requirements. UNCTAD: Geneva, 1-3 July.

Korinek, J. \& Sourdin, P., 2011, To what extent are high-quality logistics services trade facilitating?, Organisation for Economic Cooperation and Development (OECD), Paris.

MacKellar, L., Wörgötter, A. \& Wörz, J., 2000, Economic development problems of landlocked countries. Transition Economics Series No. 14, Institut für Höhere Studien (IHS), Wien Institute for Advanced Studies, Vienna.

Magerman, G., Studnicka, Z. \& Van Hove, J., 2015, Distance and border effects in international trade: A comparison of estimation methods, economics discussion papers, No 2015-69, Kiel Institute for the World Economy. http://www.economicsejournal.org/economics/discussionpapers/2015-69.

Martí, L., Puertas, R. \& García, L., 2014, 'The importance of the Logistics Performance Index in international trade', Applied Economics 46(24), 2982-2992. https://doi. Index in international trade', Applied
org/10.1080/00036846.2014.916394

Mbekeani, K.K., 2010, 'Infrastructure, trade expansion and regional integration: Global experience and lessons for Africa', Journal of African Economies 19(Suppl 1) i88-i113.

McLinden, G., Fanta, E. Widdowson, D. \& Doyle, T., 2011, Border management modernization, World Bank Publications, Washington, DC.

Mevel, S. \& Karingi, S., 2012, 'Deepening regional integration in Africa: A computable general equilibrium assessment of the establishment of a continental free trade area followed by a continental customs union', presented at the 7th African Economic Conference Kigali, Rwanda, 30 October - 2 November.

New Partnership for Africa's Development, 2012, Africa's decade of change: A reflection on 10 years of NEPAD, NEPAD Agency, UNECA and UN-OSAA.

Nordås, H.K., Pinali, E. \& Geloso Grosso, M., 2006, 'Logistics and time as a trade barrier', OECD Trade Policy Papers, No. 35 (30 May 2006), OECD Publishing, Paris. https://doi.org/10.1787/664220308873

Nuwamanya, D.K., 2012, What drives Africa's export diversification?, Federal Reserve Bank of St Louis, St. Louis, MI.

OECD/WTO, 2015, Aid for trade at a glance 2015: Reducing trade costs for inclusive, sustainable growth, OECD Publishing, Paris. https://doi.org/10.1787/aid glance2015-en

Ojala, L. \& Çelebi, D., 2015, 'The World Bank's Logistics Performance Index (LPI) and drivers of logistics performance', document préparé pour la Table ronde du Forum international des transports sur les stratégies de développement logistique et leurs indicateurs de résultats, 9-10 March 2015, Queretaro, Mexique.
Portugal-Perez, A. \& Wilson, J.S., 2008, Trade costs in Africa: Barriers and opportunities for reform, World Bank. https://doi.org/10.1596/1813-9450-4719

Portugal-Perez, A. \& Wilson, J.S., 2009, 'Why trade facilitation matters to Africa', World Trade Review 8(3), 379-416. https://doi.org/10.1017/ S147474560900439X

Puertas, R., Martí, L. \& García, L., 2013, 'Logistics performance and export competitiveness: European experience', Springer Science+Business Media New York 41, 467-480. https://doi.org/10.1007/s10663-013-9241-z

Rantasila, K. \& Ojala, L., 2012, Measurement of national-level logistics costs and performance, International Transport Forum Discussion Papers, 2012-4. International Transport Forum, Paris. http://dx.doi.org/10.1787/ 5k8zvv79pzkk-en

Redding, S. \& Venables, A.J., 2004, 'Economic geography and international inequality', Journal of International Economics 62(1), 53-82. https://doi.org/10.1016/j jinteco.2003.07.001

Sanso, M., Cuairan, R. \& Sanz, F., 1993, 'Bilateral trade flows, the gravity equation, and functional form', The Review of Economics and Statistics 75(2), 266-275. https:// doi.org/10.2307/2109432

Santos Silva, J.M.C. \& Tenreyro, S., 2006, 'The log of gravity', The Review of Economics and Statistics 88(4), 641-658. https://doi.org/10.1162/rest.88.4.641

Saslavsky, D. \& Shepherd, B., 2012, Facilitating international production networks: The role of trade logistics, World Bank Policy research Working Paper No. 6224, viewed, from https://ssrn.com/abstract=2160675.

Shepherd, B., 2013a, The gravity model of international trade: A user guide, ARTNeT Books and Research Reports.

Shepherd, B., 2013b, Aid for trade and value chains in transport and logistics, WTO/ OECD (ed.), World Trace Orginization (WTO)/OECD, from https://www.oecd.org/ dac/aft/AidforTrade_SectorStudy_Transport.pdf.

Siddiqi, M., 2008, 'Diversity is the key', African Business 2008, 66-67.

The Observatory of Economic Complexity, 2018, The top export destinations, viewed May 2019, from https://oec.world/en/resources/data/

UI Haque, I., Bell, M., Dahlman, C., Lall, S. \& Pavitt, K., 1995, Trade, technology, and international competitiveness, World Bank, Washington, DC.

UN, 1982, United Nations Convention on the Law of the Sea of 10 December 1982 https://www.un.org/Depts/los/convention_agreements/convention_overview_ convention.htm

UNCTAD, 2012, Review of Maritime Transport 2012, United Nations, Switzerland.

UNCTAD, 2015a, Review of Maritime Transport 2015, United Nations, Switzerland.

UNCTAD, 2015b, Key statistics and trends in international trade 2015, United Nations, Switzerland.

United Nations Economic Development for Africa, 2017, Economic report on Africa 2017: Urbanization and industrialization for Africa's transformation, Economic Commission for Africa, Addis Ababa.

UN-OHRLLS, 2013, The development economics of landlockedness: Understanding the development costs of being landlocked, UN-OHRLLS, New York.

UN-OHRLLS, 2016, Landlocked developing countries: Things to know, things to do, UN-OHRLLS, New York.

World Bank and International Finance Corporation, 2013, Doing business 2014 Understanding regulations for small and medium-size enterprises, The World Bank, Washington, DC

World Bank Group, 2014, Improving trade and transport for landlocked developing countries, 2nd United Nations Conference on Landlocked Developing Countries (LLDCs). Washington, DC: World Bank Group.

World Bank Group, 2016, Aggregated Logistics Performance index 2012-2018. https:// Ipi.worldbank.org/.

World Economic Forum, 2013, The Africa competitiveness report 2013, edited by World Economic Forum, Geneva.

WTO, 2005, International trade statistics 2005, World Trade Organization, Switzerland. WTO, 2015, International trade statistics 2015, World Trade Organization, Switzerland. WTO, 2017, World trade statistical review 2017, World Trade Organization, Geneva. 